Provided for non-commercial research and education use. Not for reproduction, distribution or commercial use.

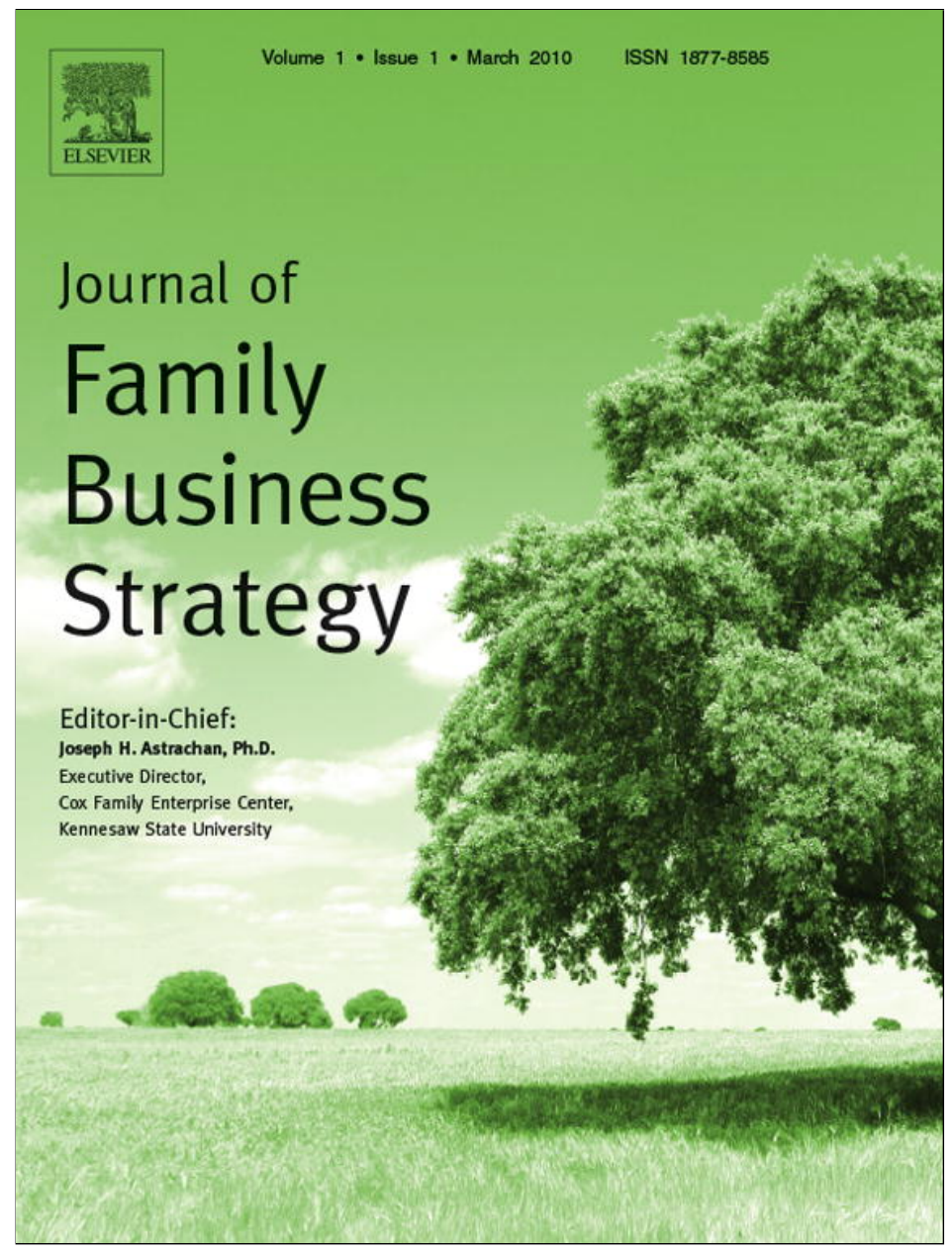

This article appeared in a journal published by Elsevier. The attached copy is furnished to the author for internal non-commercial research and education use, including for instruction at the authors institution and sharing with colleagues.

Other uses, including reproduction and distribution, or selling or licensing copies, or posting to personal, institutional or third party websites are prohibited.

In most cases authors are permitted to post their version of the article (e.g. in Word or Tex form) to their personal website or institutional repository. Authors requiring further information regarding Elsevier's archiving and manuscript policies are encouraged to visit:

http://www.elsevier.com/copyright 


\title{
Exploring the concept of familiness: Introducing family firm identity
}

\author{
Thomas M. Zellweger ${ }^{\mathrm{a}, *}$, Kimberly A. Eddleston ${ }^{\mathrm{b}, 1}$, Franz W. Kellermanns ${ }^{\mathrm{c}, \mathrm{d}, 2}$ \\ ${ }^{a}$ Center for Family Business, University of St. Gallen, Dufourstrasse 40a, CH-9000 St. Gallen, Switzerland \\ ${ }^{\mathrm{b}}$ College of Business Administration, Northeastern University, 218 Hayden Hall, Boston, MA 02115-5000, United States \\ ${ }^{c}$ Department of Management and Information Systems, Mississippi State University, Mississippi State, MS 39762-9581, United States \\ ${ }^{\mathrm{d}}$ INTES Center for Family Enterprises, WHU (Otto Beisheim School of Management), Germany
}

\section{A R T I C L E I N F O}

\section{Article history:}

Available online 6 February 2010

\section{Keywords:}

Familiness

Organizational Identity

Family Firm Image

\begin{abstract}
A B S T R A C T
Our paper contributes to the overarching question: "How does the family contribute to firm success?" We add to the nomological net of the familiness construct, by reaching beyond the components of involvement and the essence approach and by introducing organizational identity as a third dimension of familiness. As such, we investigate which families are most likely to build familiness. Specifically, the organizational identity dimension of familiness reflects how the family defines and views the firm, which can facilitate performance advantages through leveraging familiness both internally and externally. Lastly, we discuss how the combinations of components of involvement, essence and identity dimensions of familiness interact and explain why and how some families are a key resource to their firms while others add little value to their organizations.
\end{abstract}

(c) 2009 Elsevier Ltd. All rights reserved.

\section{Introduction}

Family firms have been established as a unique area of research that has experienced exponential growth in recent years (e.g., Debicki, Matherne, Kellermanns, \& Chrisman, 2009; Sharma, Hoy, Astrachan, \& Koiranen, 2007). Generally, research has focused on two distinct aspects. First, research has tried to explain differences between family firms and non-family firms (e.g., Chrisman, Steier, \& Chua, 2008); and second, research has focused on variations in behaviors among family firms (e.g., Chrisman et al., 2008). However, all these endeavors are guided by one overarching question: "How does the family contribute to firm success?"

In an attempt to answer the posed question, prior research has developed the concept of familiness (e.g., Habbershon \& Williams, 1999; Habbershon, Williams, \& MacMillan, 2003). The importance of this construct has been highlighted by Pearson, Carr and Shaw (2008, p. 949) who state that "[the] identification and isolation of a construct [familiness] unique to family firms is both groundbreaking and important for family firm research." Rooted in the Resourcebased view (RBV), Habberson and colleagues (1999) define familiness as the bundle of idiosyncratic internal resources that

\footnotetext{
* Corresponding author. Tel.: +41712247100. E-mail addresses:

thomas.zellweger@unisg.ch (T.M. Zellweger), k.eddleston@neu.edu

(K.A. Eddleston), fkellermanns@cobilan.msstate.edu (F.W. Kellermanns).

${ }^{1}$ Tel.: +1 617373 4014; fax: +1 6173738628 .

2 Tel.: +1 662325 2613; fax: +1 6623258651
}

exist due to the involvement of the family in the firm. They suggest that family involvement leads to familiness which can be viewed as unique, inseparable, and synergistic resource and capabilities arising from family involvement and interactions.

While a growing body of research has added to the nomological net of familiness (e.g., Chrisman, Chua, \& Sharma, 2005; Habbershon \&Williams, 1999; Habbershon et al., 2003; Naldi, Nordqvist, Sjoberg, \& Wiklund, 2007; Pearson, Carr, \& Shaw, 2008; Rutherford, Kuratko, \& Holt, 2008), the concept of familiness still remains somewhat obscure (e.g., Pearson et al., 2008; Rutherford et al., 2008). Indeed, Sharma (2008) suggests that the fundamental task of evaluating the construct itself - its dimensions, antecedents, and consequences has been neglected, slowing down the theory-building aspirations of the field (cf., Zahra \& Sharma, 2004). Chrisman, Chua and Sharma (2005) called for research that identifies family firms' uniqueness, focusing on how the family's involvement is a root cause of their distinctiveness. These authors offered two dimensions of family involvement that help to explain familiness: the components of family involvement and the essence of such involvement. While the components of involvement approach focuses on family ownership and control, setting a minimum threshold of family influence, the essence approach centers on the behaviors and synergistic resources and capabilities a family contributes to a business. Additionally, recent theory that considers the dynamics of the overlapping family and business systems proposes that organizational identity may be a key source of competitive advantage for family firms since their "family identity is unique and therefore impossible to completely copy" (Sundaramurthy \& Kreiner, 2008: 416). Indeed, adding organizational identity to the components of involvement and essence 
approaches to explain family firm performance seems warranted given preliminary research by Zellweger and Kellermanns (2008) which shows that identity concerns in family firms explain a significant portion of performance variance in these firms. Moreover, departing from the components of involvement and essence approaches, Eddleston (2009) argued that a family's configuration based on these three dimensions of family involvement explains how some family firms are particularly proficient at creating a competitive advantage.

Drawing on the components of involvement and essence approaches (Chrisman, Chua, Pearson, \& Barnett, 2009b; Chrisman et al., 2005; Chua, Chrisman, \& Sharma, 1999) and organizational identity theory (e,g., Ashforth \& Mael, 1996; Whetten \& Mackey, 2002), this paper takes a closer look at how familiness can vary among families. However, we need to stress that our discussion about familiness is not intended to define family firms in more detail. Instead, we argue that familiness is a multi-dimensional construct that needs to be better understood, as it can affect the competitive advantage of family firms (see also Habbershon \& Williams, 1999; Habbershon et al., 2003). Accordingly, we view family firms as heterogeneous and acknowledge that while some families can be assets to their firms and build familiness, other families could be characterized more as liabilities. This supports recent research that has shown that family influences can have both positive and negative effects on the family firm (e.g., Kellermanns, Eddleston, Sarathy, \& Murphy, in press). While we acknowledge the potential for detrimental consequences of family involvement, in the present paper we specifically focus on the positive contributions a family can make to an organization. Our multi-dimensional view of family influence is aimed at explaining differences among families and why some families are more of a resource to their firms than others. While previous research has focused on the "how" (Arregle, Hitt, Sirmon, \& Very, 2007) and "what" (Pearson et al., 2008) of familiness, we therefore focus on the "who"-that is, "who are the families that are most likely to build familiness?"

Our paper proceeds as follows. First, we briefly review the initial conceptualization of familiness and recent research exploring the concept. To make the case for a third dimension of the family aspect of familiness, we then discuss the strengths and weaknesses of the components of involvement and the essence approaches. Second, we describe our multi-dimensional view of the family aspect of familiness. In the subsequent discussion, we outline our theoretical contributions, mention limitations, and point to possible avenues for future research.

\section{Theoretical background and hypothesis development}

According to the RBV, resources are at the heart of competitive advantage and, therefore, business success. Despite recent criticism of the RBV, for example limitations regarding empirical testing, the assumptions of its central precepts and the role of stakeholders in appropriating residual claims (Arend, 2006; e.g., Coff, 1999; Priem \& Butler, 2001), the RBV remains one of the most prominent theoretical foundations of today's management research (e.g., Newbert, 2007). The RBV describes how resources can contribute to the competitive advantage of organizations (e.g., Barney, 1991; Dierickx \& Cool, 1989; Grant, 1991; Peteraf, 1993).

Scholars have also applied the RBV to the field of entrepreneurship (e.g., Alvarez \& Barney, 2004), and to the study of family firms (e.g., Chrisman, Chua, \& Kellermanns, 2009a; Eddleston, Kellermanns, \& Sarathy, 2008; Habbershon \& Williams, 1999). Within this theoretical lens, Habbershon and Williams (1999) first introduced the term "familiness," describing it as the idiosyncratic bundle of resources and capabilities resulting from the interaction of the family and business systems (Habbershon et al., 2003: p.
451). Chrisman, Chua, and Litz (2003) later described the concept as "... resources and capabilities related to family involvement and interactions" (p. 468). These authors argued that a positive contribution by the family leads to distinctive familiness ${ }^{3}$ which can serve as a source of competitive advantage for the family firm. Thus, familiness is often used as a unique element that can differentiate family and non-family firms and also discriminate performing from underperforming family firms (Pearson et al., 2008).

In order to understand the family's role in supporting the competitiveness of the family firm, it is key to develop an understanding about different family-based attributes of family firms that can create familiness. Such an approach needs to reach beyond the anecdotal description about strengths and weaknesses of family firms and provide answers to the question: which types of families contribute to their family firms; that is, who are the families that are best able to create familiness?

Much research has examined the link between a family firm's resources/capabilities and its competitive advantage/performance. For example, previous research has explored how human capital, social capital, patient financial capital, and governance structure contribute to family firm performance (i.e., Danes, Stafford, Haynes, \& Amarapurkar, 2009; Sirmon \& Hitt, 2003). Other research has focused on how the family's aspirations, visions and values impact their strategic choices (Carney, 2005; Chrisman, Chua, \& Zahra, 2003; Naldi et al., 2007). In contrast, our paper focuses on the different ways a family can be involved in the family firm. As such, we hope to answer the call for research by Pearson et al. (2008) to consider the various dimensions of family-related social factors that create familiness.

Building on past research (e.g., Ben-Porath, 1980; Eddleston et al., 2008; Naldi et al., 2007; Sirmon \& Hitt, 2003; Zellweger, 2007; Zellweger \& Astrachan, 2008; Zellweger \& Nason, 2008) and acknowledging that other theoretical lenses may also provide fruitful and complementary avenues for investigating sources and consequences of familiness (Pearson et al., 2008; Sharma, 2008), we focus on the family aspect of familiness to explore ways in which a family can influence the family firm. Thereby we reach beyond the component of involvement and the essence approaches (e.g., Chrisman et al., 2009b, 2005), and introduce organizational identity as a third element. In the next sections we discuss these three dimensions in detail.

\subsection{The family aspect of familiness}

Chrisman et al. (2005) introduced the "components of involvement" and "essence" approaches to the family firm literature to distinguish family from non-family firms and to unearth the linkage between family involvement and competitiveness of family firms.

The components of involvement approach consider the family's involvement in ownership, management or control (Chrisman et al., 2005). It is the basic necessary condition for a family to exercise influence on the family firm and sets the minimum threshold for considering a firm a family firm. This approach contends that family involvement in ownership, management or control is sufficient to classify a firm a family business (Pearson et al., 2008). Many other research studies require even fewer attributes to consider the existence of a base level of familiness (for an overview see Rutherford et al., 2008, p. 1094-1095). Proponents of this view believe that the mere existence of family in a business can create familiness. Indeed, Steier (2003) argues that family's

\footnotetext{
${ }^{3}$ In the remainder of the paper we use the term "familiness" as a substitute for distinctive familiness.
} 
involvement in management can offer much in the way of explaining family firm behaviors.

However, criticism has arisen regarding the component of involvement's ability to explain performance differences in family firms. Such criticism partly relates to the underlying assumptions and definition of a family firm. In particular, a definition that captures combinations of levels of family involvement in ownership and management may be prone to misclassifications. For example, such an approach may overlook firms that are owned by a controlling family that dictates the firm's decisions, yet the family is not directly involved in the firm's management. Applying only a component of involvement perspective would erroneously classify these firms as non-family firms, and hence overlook a large fraction of firms that are strongly influenced by a controlling family. Similarly, such a perspective can mistakenly classify businesses as family firms when the firm is controlled by a family but there is little family involvement, i.e., passive holding company (Chua et al., 1999).

Furthermore, while the components of involvement approach holds the promise of being operational and measurable, it seems underspecified in terms explaining how and why family involvement impacts strategic processes that lead to competitive advantages, limiting the practical applicability of the approach. While the theoretical roots of the components of involvement approach, focusing on combinations of management and ownership control, can be found in agency theory, this approach is unable to capture altruistic and stewardship-based behaviors that appear to be critical factors in explaining performance differences among family firms (e.g., Corbetta \& Salvato, 2004; Eddleston \& Kellermanns, 2007; Schulze, Lubatkin, \& Dino, 2003). Similarly, the components of involvement approach does not account for the unique resources the family is able to contribute to the firm due to the systemic interaction between family and business (Habbershon et al., 2003). Thus, it appears that the components of involvement approach to defining family firms are often a matter of convenience for researchers.

For these reasons it is argued that family involvement in terms of ownership, management and control may not be sufficient in explaining how the family contributes to the business. Family ownership, management and control may only depict a family's potential to influence a family firm. Chrisman and colleagues (Chrisman et al., 2005) argued that family members must purposely influence the family firm in order to make a sustainable difference in the resource endowment of the firm. Therefore, the components of involvement approach characterizes the simplest form of family involvement in the family firm and represents the first step in distinguishing family businesses, albeit a necessary condition in creating the potential for familiness.

In contrast to the components of involvement approach, the essence approach argues that "family involvement must be focused and directed toward behaviors that produce distinctiveness before the firm can be classified a family firm" (Pearson et al., 2008: 966). While most research assumes that family involvement will translate into family influence that shapes the organization (Chua et al., 1999; Gómez-Mejía, Hynes, NúñezNickel, \& Moyano-Fuentes, 2007), such influence is not automatic (Chrisman et al., 2009b, 2005). Thus the essence approach is a matter of behavior of the people who control the firm. Such behavior is determined by the unique processes and synergistic resources and capabilities contributed to the business by the family and the transgenerational vision that may perpetuate these values (Habbershon \& Williams, 1999).

The essence approach suggests that when the family displays a transgenerational vision for the business and the family controls the firm, feelings of personal and social fulfillment arise that cause family members to guard the well-being of the business (Arregle, Hitt, Sirmon, \& Very, 2007), to place the firm's objectives ahead of their own (Zahra, Hayton, Neubaum, Dibrell, \& Craig, 2008) and to provide human, social and financial capital to the firm (Danes et al., 2009). For example, as a consequence of family involvement, family members may provide financial support through outside sources of income, emotional support through encouragement, and instrumental support through knowledge and human capital to the family firm (Danes et al., 2009; Van Auken \& Werbel, 2006). In this way, the essence approach is able to describe different types of family firms and behaviors, thereby capturing the heterogeneity of family firms (Westhead \& Howorth, 2007). It portrays the processes and behaviors transcending ownership and management through which competitive advantage is created and introduces transgenerational vision as an essential part of what family firms exemplify.

While considering both the components of involvement and essence approach has contributed to theoretical and empirical insights on family firms, why family members engage themselves in the business or invest in the firm remains largely unknown. That is, why do some family members contribute to the firm beyond the levels of normal managers or owners? While the RBV holds promise regarding the conceptual link between internal aspects of the firm and the firm's competitiveness (Barney, 1991), the underlying processes that lead to competitive advantages are particularly difficult to uncover in family firms. This difficulty is not only tied to the multitude of resources at play and the distinctiveness of their usage, but also to the idiosyncrasy of families and the resulting uniqueness of a family's influence on a firm's resource base. Furthermore, since transgenerational vision is an essential part of the essence approach, it is unclear whether family-based resources (e.g., knowledge, social capital) can be transferred across generations. Finally, given its roots in the RBV, the measurement and operationalization of family-based resources, beyond the measurement of sheer resource stocks, is challenging. In summary, while the components of involvement approach provides an objective assessment of the family firm, setting a minimum threshold in defining a business as a family firm, the essence approach to family influence reflects the behaviors that can embody the family firm.

However, the ability to assess a firm's familiness based on the components of involvement and essence approach seems limited in light of the advances in entrepreneurship literature. The entrepreneurship literature has recognized that an entrepreneur's family often provides assistance to a new venture, both within and outside the boundaries of the existing family business (group) (e.g., Goffe \& Scasse, 1985; Nordqvist \& Zellweger, 2010). Family is a key contributor and source of labor (often intermittent unpaid labor) during the start-up and expansion phases of a business (Chang, Memili, Chrisman, Kellermanns, \& Chua, 2009; Fock, 1998). Therefore, given recent advances in the entrepreneurship literature that has acknowledged a family's influence on any business family and non-family firms alike - an additional dimension to family influence, beyond the components of involvement and essence approaches, seems necessary.

What is needed is a complementary extension to the components of involvement and essence approaches that distinguishes when the family is a substantive part of the firm, versus merely a symbolic or supportive element that is not integrated into firm behavior or the organization's culture. An approach that builds on the organization's identity seems warranted given that how a firm defines itself should discriminate family from nonfamily firms. Indeed, Westhead and Cowling (1998) showed that $17 \%$ of the firm leaders in their sample did not perceive themselves to be a part of a family firm despite the fact that the firm was majority controlled by a family. Additionally, these authors showed that $15 \%$ of the firm leaders in the sample perceived their firm to be a family firm, despite a low level of family control. 
Table 1

Comparing components of involvement, essence and organizational identity dimensions of familiness.

\begin{tabular}{|c|c|c|c|}
\hline & Components of involvement & Essence approach & Organizational identity \\
\hline Definitional focus & $\begin{array}{l}\text { Focus on degrees of family management, } \\
\text { ownership and control. } \\
\text { Captures the presence of the family } \\
\text { in the firm. }\end{array}$ & $\begin{array}{l}\text { Focus on behaviors and synergistic resources } \\
\text { contributed to the business by the family. } \\
\text { Captures how family members behave in } \\
\text { the firm. }\end{array}$ & $\begin{array}{l}\text { Focus on family firm identity } \\
\text { which is unique given the } \\
\text { idiosyncrasy of the family. } \\
\text { Captures how the family } \\
\text { defines and views the firm. }\end{array}$ \\
\hline $\begin{array}{l}\text { Familiness/competitive } \\
\text { advantage emanates } \\
\text { from... }\end{array}$ & $\begin{array}{l}\text {..family's involvement in management } \\
\text { and/or ownership. }\end{array}$ & $\begin{array}{l}\text {...unique processes and synergistic } \\
\text { resources and capabilities that contribute to } \\
\text { the business by the family and the } \\
\text { transgenerational vision that may perpetuate } \\
\text { these values. }\end{array}$ & $\begin{array}{l}\text {... projecting a family firm image } \\
\text { towards internal and external } \\
\text { stakeholders of the firm. }\end{array}$ \\
\hline Strengths & $\begin{array}{l}\text { Operational definition used in many } \\
\text { studies to distinguish family from } \\
\text { non-family firms. } \\
\text { Easy to measure. } \\
\text { Suitable for studies comparing family } \\
\text { and non-family firms (e.g., stock market). } \\
\text { Sets the boundary condition for family } \\
\text { involvement. }\end{array}$ & $\begin{array}{l}\text { Inclusive definition, which covers a wide } \\
\text { variety of family firms. } \\
\text { Investigates the processes transcending } \\
\text { ownership and management through } \\
\text { which competitive advantage is created. } \\
\text { Recognizes the inherent heterogeneity } \\
\text { of family firms. } \\
\text { Includes the transgenerational vision } \\
\text { as a defining characteristic. }\end{array}$ & $\begin{array}{l}\text { Captures the idiosyncrasy of } \\
\text { family firms through exploring } \\
\text { identity of the family. } \\
\text { Captures family identity beyond } \\
\text { boundaries of components of } \\
\text { involvement and essence approaches. } \\
\text { Solid theoretical foundation, } \\
\text { with well defined ways through } \\
\text { which FB identity impacts } \\
\text { performance (see Table } 2 \text { ). }\end{array}$ \\
\hline Challenges & $\begin{array}{l}\text { Explains only the family's potential } \\
\text { to influence a firm. } \\
\text { Is unable to capture how family } \\
\text { involvement impacts strategic processes } \\
\text { that lead to competitive advantages, } \\
\text { and thus limits the approaches' } \\
\text { theoretical validity. } \\
\text { Misclassifications: classifies firms as } \\
\text { family (non-family) firms being } \\
\text { controlled by a family but where otherwise } \\
\text { family involvement is weak (strong). }\end{array}$ & $\begin{array}{l}\text { Processes leading to competitive advantages } \\
\text { difficult to uncover given multitude of } \\
\text { resources, distinctiveness of their usage, } \\
\text { and idiosyncrasy of family's influence } \\
\text { on firm's resource base. } \\
\text { Transgenerational vision raises questions } \\
\text { about transferability of resources } \\
\text { across generations. } \\
\text { Measurement and operationalization of } \\
\text { family influenced resources poses challenges. } \\
\text { Misclassifications: a firm may benefit from } \\
\text { family influenced resources (e.g., start-up } \\
\text { venture) but still not see itself as a family firm. }\end{array}$ & $\begin{array}{l}\text { Narrow theoretical focus and } \\
\text { prediction about the sources } \\
\text { of familiness. } \\
\text { Typologies of different family } \\
\text { firm identities missing. }\end{array}$ \\
\hline
\end{tabular}

As such, applying an identity-based rationale uncovers a theoretically and practically relevant facet of what family firms represent. We introduce organizational identity as an overlooked source of familiness by providing a vision for the firm and directing family and non-family members to consider "who they are as an organization" when making decisions pertaining to the organization. The organizational identity approach, with its emphasis on family firm identity, captures the family's perception of the business - "Are we a family firm?" - and directly recognizes those families who are likely to create familiness. In the next section, we discuss organizational identity theory in more detail, and then link this theoretical perspective as a third dimension of family influence to the competitive advantage of these firms. Below Table 1 provides an overview on the three dimensions of familiness discussed in our paper.

\subsection{Organizational identity theory}

Features of an organization that are considered to be the most central, distinctive and enduring are captured through organizational identity theory (Albert \& Whetten, 1985). Organizational identity provides a sense of continuity and distinctiveness to the organization, as it describes the collective behavior and identity of the organization that is rooted in the organization's history and values (Ashforth \& Mael, 1996; Gioia, Schultz, \& Corley, 2000; Nag, Corley, \& Gioia, 2007). The values and beliefs residing in the organization are continuously expressed through interactions between organizational members. In turn, these interactions provide organizational members with an interpretive belief system that provides meaning to the organization and its members (Gioia, 1998).
Organizational identity describes how organizational members develop a shared understanding of the inner processes, workings and culture of the organization and how this understanding affects the behavior of these individuals, the organizational strategy and change (Ravasi \& Schultz, 2006). Accordingly, organizational identity can be regarded as a sense-making tool (Fiol, 1991; Weick, 1995) that, provides "the context within which members interpret and assign profound meaning to surface-level behavior" (Ravasi \& Schultz, 2006: 437). In addition to sense making, organizational identity has a sense-giving function that guides "how members of an organization should behave and how other organizations should relate to them" (Ravasi \& Schultz, 2006: p. 435). Accordingly, organizational identity can be seen as a mechanism that both influence the behavior of organizational members and give them an interpretative framework within which behaviors occur (Whetten \& Mackey, 2002) ${ }^{4}$. Through identification, the organization becomes an extension of the employee's self and embodies the perception of "oneness" an employee feels with an organization (Ashforth \& Mael, 1996).

A recent study by Nag, Corly and Gioia (2007) showed that while organizational identity imparts a cognitive frame and meaning for the work practices of organizational members, it also inheres in work practices, particularly in the way that

\footnotetext{
${ }^{4}$ Due to the proximity of the terms, it seems important to define the terms "organizational identity" and "organizational image", as used in the present paper. We follow Whetten and Mackey (2002) and define organizational identity as that which is most central, enduring and distinctive about organizations. Building on an organizational identity, organizational image is conceived as identity congruent messages invoked by members of the organization. The self-defined identity and self-projected image towards others are distinct from the organizational reputation concept.
} 
members use knowledge to accomplish work. Thus, organizational identity is more than a cognitive view of an organization; it also embodies "the collective practices that characterize how organizational members conduct their daily work" (Nag et al., 2007: p. 824). Indeed, through a unique set of beliefs, values and practices, organizational identity differentiates one organization from others in the eyes of organizational members and stakeholders (Scott \& Lane, 2000).

This discussion is particularly applicable to family firms as they can develop unique identities not only through the overlapping of the family and business system (Barnett, Eddleston, \& Kellermanns, 2009; Sundaramurthy \& Kreiner, 2008; Tagiuri \& Davis, 1992), but also through the varying degrees of involvement and influence the family exercises (Chrisman et al., 2009b, 2005). The integration of the various beliefs that originate from the family and the business, often tied to their common history, may thus explain how the distinctiveness of organizational identity arises. This view alludes to Klein, Astrachan, and Smyrnios (2005) who suggest that the values of key people in an organization - their politics, communication style, conflict management, and preference for centralization/decentralization - form an essential part of organizational culture.

A strong family firm identity can be created in many ways. When family members feel a strong sense of belonging to the family firm this feeling is often tied to the family members selfworth and self-esteem and the perception that the family firm represents an extension of themselves (Dyer \& Whetten, 2006). Because family firm members are likely to view their business as an extension of their family, they often go to great lengths to create and maintain a positive organizational identity (Dyer, 2006). They understand that they cannot switch families if their family firm's image is damaged. Sundaramurthy and Kreiner (2008) point out that kinship, a shared family name, common history, and familiarity have the unique potential to develop a strong identity in family firms, inspiring family members to uphold the values and goals of the family firm. Family firm identity can create a sense of oneness and shared destiny for family members, building common ground for them to rally around and leading them to view the fulfillment of family firm obligations as a source of pride (Sundaramurthy \& Kreiner, 2008). When family members are highly dedicated to the business and members believe that they have a common family responsibility to see the business prosper (Cabrera-Suárez, Saá-Pérez, \& García-Almeida, 2001), they are motivated to contribute to the firm.

Additionally, as a result of a strong family firm identity, the firm is likely to benefit from involved and participative family managers. Indeed, active participation and open communication build commitment to an organization and foster a sense of belonging (Smidts, Pruyn, \& Van Riel, 2001). Firms with higher levels of family member exchange, characterized as having family employees who share ideas, feedback and expectations of oneanother, are more successful than those firms where family members do not communicate or exchange information (Kellermanns \& Eddleston, 2007). Family members who frequently interact and communicate, are more likely to create a common point of view regarding their family business (Sorenson, Goodpaster, Hedberg, \& Yu, 2009). In turn, the shared values and goals among family members may ease discussions, speed-up decisionmaking, and develop consensus regarding the strategic direction of the firm. Indeed, a shared identity and common point of view enhance the quality of decision-making (Mustakallio, Autio, \& Zahra, 2002).

It is noteworthy that the benefit of an organizational identity may extend beyond the family. Indeed, research has suggested that the concept of family can be extended to non-family members (Karra, Tracey, \& Phillips, 2006). When the entire organization embraces the values and goals of the family, unique advantages can be realized. For example, the family firm could benefit from stewardship behavior from family members (e.g., Eddleston \& Kellermanns, 2007), as well as from non-family members. In such a scenario, non-family members would behave as stewards of the family firm, engaging in supportive and innovative behaviors that benefit the entire organization (Corbetta \& Salvato, 2004). As such a family firm identity can extend to employees who are not family members.

Likewise, a family firm identity that integrates participative decision-making may foster a strategy process that builds familiness. A participative strategy process supports family members' identification with the firm, helping them to understand the challenges facing the firm as well as the firm's strengths, weaknesses, resources and capabilities (Eddleston \& Kellermanns, 2007). Indeed, fast growth, high performing family firms have been found to encourage participation in developing long-term goals and strategies (Ueda, 2004). Additionally, participative strategy making may also ensure that the ideas, goals and capabilities of family and non-family employees are combined and aligned. Such participative strategy making helps a family firm to avoid groupthink and it also fosters strategic renewal (Sirmon, Arregle, Hitt, \& Webb, 2008). For example, Kellermanns, Eddleston and Zellweger (2008) suggest that participative strategy-making distinguishes the most entrepreneurial family firms since the family is able to complement the fresh perspectives of non-family directors. This sharing of diverse perspectives may thereby enhance a family firm's ability to identify and exploit entrepreneurial opportunities. By combining the tacit knowledge of family members with the unique perspectives of the board of directors, competiveness should be facilitated.

While we have discussed how organizational identity can help a family firm to develop familiness internally, organizational identity may also contribute to familiness that extends externally to the business. Organizations tend to manage internal and external relationships according to the same principles, values and goals (Rousseau \& Wade-Benzoni, 1994). As such, firms tend to portray the same identity toward external stakeholders as they do toward internal stakeholders (Brickson, 2007). Organizational identity influences external audiences' interpretation of the firm's image and branding practices (Karreman \& Rylander, 2008) thereby affecting the public's perception of the firm's products, strategies and organizational members (Fombrun \& Shanley, 1990). Since a family's identity is unique, a family firm identity may be an important source of competitive advantage in the marketplace (Sundaramurthy \& Kreiner, 2008). Often, the family becomes a salient image of the firm in the eyes of the public. Upholding the firm's image may become a particularly significant concern in the case of eponyms, when the family name is used in the firm's name. Eponyms may be a unique way for a family firm to demonstrate their connection to a family and support of family values. By tying the family's name to the firm, the family firm is able to signal to the public the family's values, beliefs and norms (Craig, Dibbrell, \& Davis, 2008). In this way, the family comes to personify the business, becoming an external resource for the family firm.

Being known as a "family firm" may be perceived as a positive and distinct attribute in the minds of consumers thus contributing to firm performance. Many family firms also realize that capitalizing on their family firm status may be a way to build a distinct corporate brand. Promoting a business as a family business to customers, suppliers and financiers capitalizes on the public's perception of family firm as trustworthy, customer-focused and quality-driven (Craig et al., 2008; Ward \& Aronoff, 1995). Indeed, developing a family-based brand identity has been shown to positively contribute to firm growth and profitability through its 
Table 2

The link between family firm identity and competitiveness.

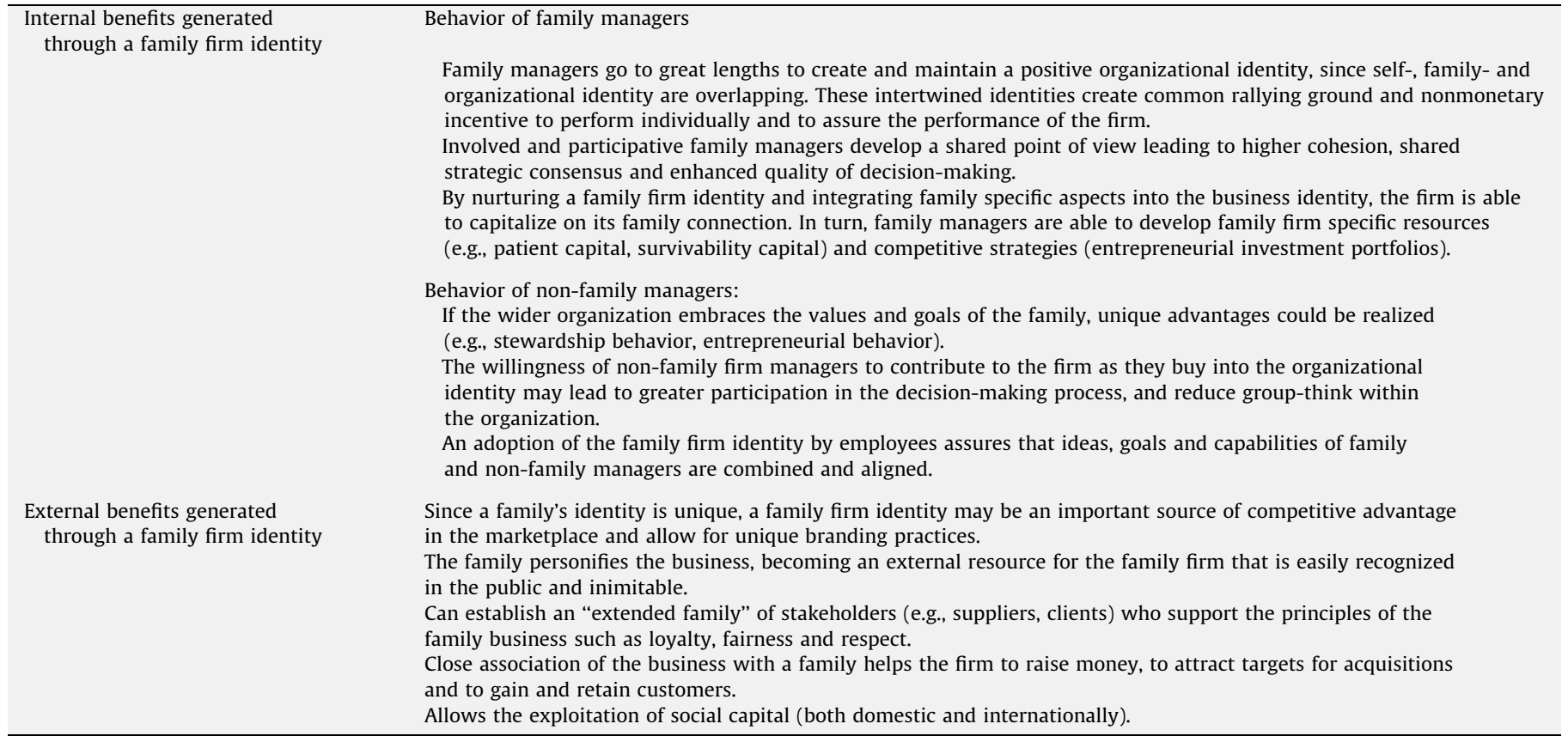

influence on customer-centered values (Craig et al., 2008). Similarly, a recent study by Memili, Eddleston, Zellweger, Kellermanns and Barnett (in press) demonstrated that firms that communicate their family firm identity to external stakeholders reap performance benefits. In this way the family firm can establish an "extended family" of stakeholders who support the principles of the family business such as loyalty, fairness and respect (Sorenson et al., 2009) thereby enabling the firm to build a competitive advantage that improves performance.

Another way a family firm identity can lead to externally generated benefits is through community-level social capital. Community-level social capital embodies the information, contacts and reciprocity that family businesses often share through a community of family-controlled organizations (Lester \& Cannella, 2006). Family businesses seem to possess a sense of community that provides social support and information to each other (Lester \& Cannella, 2006). This type of social capital creates value for a family firm because it reduces transaction costs related to the search and screening of information and also aids in contract enforcement (Arregle et al., 2007; Carney, 2005). For instance, family firms often help one-another navigate uncertainty in their environments by providing business tips and access to new markets (Lester \& Cannella, 2006). Research on internationalization also supports this view of family firms as being supportive of one-another. Gallo and Vilaseca (1996) showed that family firms use alliances and cooperative arrangements most effectively when venturing abroad. Therefore, firms that nurture their family firm identity may be able to gain access to a unique type of communitylevel social capital that assists with their operations and performance.

Table 2 summarizes the ways in which a family firm identity may create familiness and hence contribute to the competitiveness of family firms.

While we have discussed how organizational identity reflects a family's influence on a family firm and can be an internal and external resource to a family firm, it should also be mentioned that not all family firms choose to foster a family firm identity. Recent research drawing from organizational identity theory acknowledges that family firms have two relevant identities - the family and the business - that can be segmented or integrated to various degrees (Sundaramurthy \& Kreiner, 2008). As mentioned earlier, firms that are controlled by families do not always see themselves as "family firms," and sometimes firms that are not controlled by families define themselves as "family firms" (Westhead \& Cowling, 1998). Sorenson and colleagues (2009: p. 250) note that "the creation of a family business does not guarantee the development of a family point of view." Such a scenario reflects Pearson and colleagues' (2009) contention that family firms with weak family relationships may closely resemble non-family firms. Therefore, just as there is variability in the degree of family involvement and family essence in family firms, there is also variability in the degree to which a family firm chooses to integrate their family into their organizational identity. Some family firms may choose to ignore or downplay their family firm status, resembling non-family firms to stakeholders.

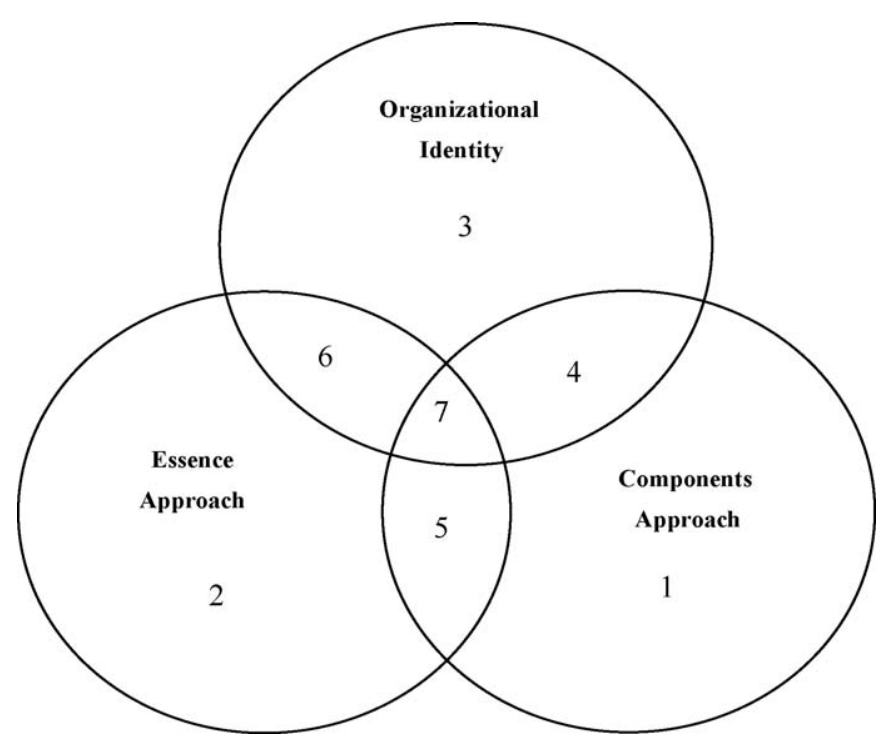

Fig. 1. Dimensions of familiness. Adapted from Eddleston (2009). 


\subsection{Integrating the dimensions}

As we outlined earlier, all three dimensions have merit in trying to discern why some family firms are more likely to create familiness than others. Accordingly, all three dimensions should be considered when trying to assess the competitiveness of family firms and their family firm specific resources. Fig. 1 portrays the integration of organizational identity with the components of involvement and essence approaches, offering a three-dimensional conceptualization of a family firm's potential to develop familiness.

The components of involvement approach encompass actual observable elements that describe the family firm (e.g., ownership stake, percentage of family managers). The essence approach aims to address the influence of the family on the firm's resource base with the family pursuing a transgenerational vision. Organizational identity adds to these two dimensions by assessing the degree to which family and non-family members see the firm as a family business. In other words, the components of involvement dimension captures the presence of the family in the firm, the essence approach captures family members behavior in the firm, and the organizational identity dimension reflects how the family defines the firm and how the firm operates as a whole. Where a firm is located on the three-dimensional model will have a profound impact on the firm's ability to create familiness.

Family involvement-only firms (sector 1 in Fig. 1): for example, if we consider each component separately, the components of involvement approach, with its emphasis on ownership and control, should have the greatest impact on factors related to monetary incentive systems, risk-taking and profit-sharing. It may be particularly applicable to the investigation of larger firms, where family firm specific resources beyond financial capital are limited. An example of a solely components-oriented firm would be an investment holding vehicle with family ownership but nonfamily management. The family's behavioral impact is limited and it does not necessarily see the business as a "family business." The firm is merely a source of wealth for family members. Here, the creation of familiness may be limited, since the family's influence on the business, beyond financial capital, is scarce.

Essence-only firms (sector 2 in Fig. 1): in contrast, the essence approach, with its emphasis on behavioral aspects, resource endowment and usage, reflects the family's support for the business as well as any conflicts that arise between work and family. An example of a solely essence-oriented firm would be a business owner, say a restaurant owner, who utilizes family labor, perhaps unpaid, yet the owner does not view the business as a family firm nor do family members share ownership of the firm. Perhaps the business owner's wife assists with bookkeeping or his children periodically wait tables at his restaurant. But to the owner, it is his business. While the business utilizes some behavioral advantages of familiness - family members contributing to the operations of the business - the firm does not capitalize on sources of familiness that originate from family management or family firm identity.

Family firm identity-only firms (sector 3 in Fig. 1): lastly, the organizational identity approach emphasizes the perception of family firm identity-are we a family firm? As such, organizational identity should have a significant impact on factors at the interface of the family and the firm such as issues related to the image of the firm, and the shared social identity of employees. An example of a solely identity-oriented firm would be one in which an entrepreneur starts a business with the goal that her daughters will someday join the business. Another example would be a business owner who takes over her father's business, yet no other family members contribute to or share ownership of the business. While both scenarios describe firms that do not employ family members or have family ownership, the entrepreneurs still see their firm as a "family firm" and make decision accordingly. However, the ability to generate familiness is restrained in these scenarios since opportunities related to family's contribution to management and control is forgone and the firms lack family support.

As the approaches overlap, one can see how the complexity of understanding and predicting family firm behavior intensifies. It clearly depicts why the goals and values among family firms may differ and why the concerns of family firms can be quite different from those of non-family firms. It also depicts how some family firms may be better able to create familiness than others. Families who are most likely to develop familiness would be those who combine the components of involvement, essence and family firm identity, creating synergy between the family and the business that contributes to family firm performance (sector 7 in Fig. 1). These firms possess family involvement, reflect the essence of the family and define themselves as family firms thus extracting the multiple benefits of family influence and capturing the advantage of family involvement in an enterprise. For example, when SC Johnson advertises with the slogan "A family company," it can be expected that the firm is harnessing the positive attributes consumers associate with family involvement in a firm. In its communication with stakeholders, Johnson promotes its strong organizational culture that embodies a family-spirit with high employee commitment and loyalty ${ }^{5}$. Similarly, Pictet, one of the largest Swiss private banks, presents itself as a family-owned firm with a family heritage over two hundred years old. At Pictet the family supports the firm through involvement in management and ownership. Moreover, the seven managing partners stand personally behind the bank's commitments, building an image of trust and personalized customer service in the marketplace. These elements portray what is central about the opportunities related to the combination of the three dimensions of familiness-as a means of differentiating themselves in a crowded and instable marketplace where solidity, continuity and reliability are critical in achieving competitiveness.

In comparison, families that combine the components of involvement and organizational identity (sector 4 in Fig. 1) may see themselves as family firms and possess the family control to impact decision-making, but without the essence of the family the family-like behaviors and transgenerational vision - the firm may never realize the full benefits of family influence that come from altruistic acts and family support.

Another scenario would be a family firm that combine only the components of involvement and essence approaches (sector 5 in Fig. 1). Several large family firms such as Wal-Mart and IKEA fall into this sector: these firms are controlled and supported by families, however, they do not make a conscious effort to link the family image with its products. These families may want to avoid misperceptions of their firms in the public or conceal the family firm aspect for privacy concerns of the family. Without family specific organizational identity, however, these firms may lack the common vision necessary to direct and capitalize on family influence. In particular, smaller firms that fall into this category may not realize the external social capital and consumer goodwill that can accrue to organizations that label themselves "family firms."

Finally, the combination of essence approach and identity approach, in absence of components of involvement, reflects firms that seek to be family-like (sector 6 in Fig. 1). For example, Southwest Airlines often portrays itself as a family of employees. For example, on their website they state, "Being a Southwest Employee makes you part of the Southwest family! As our Company

\footnotetext{
${ }^{5}$ This information about involvement, essence and identity are taken from www.scjohnson.com.
} 
grows, we know how important it is to keep those family ties." Small businesses often proclaim their family-like culture in advertisements and explain how their employees go above and beyond the call of duty to ensure customer satisfaction. Therefore, this scenario is quite interesting in that it captures how non-family firms may be able to harness some of the capabilities of familiness to compete in the marketplace.

In sum, our multi-dimensional view of family aspects of familiness demonstrates the heterogeneity among families and explains why some families are a key resource to their firms while others add little value to the firm. It also sheds light on how nonfamily firms may be able to build familiness by imitating some of the elements often seen as unique to family firms.

\section{Discussion}

Supporting research on familiness, in this paper we offer a multi-dimensional model of family influence in the family firm. While each dimension (components of involvement, essence and family firm identity) reflects a unique way that families can influence the family firm, the model also acknowledges that these dimensions often overlap and intermingle. In building familiness, it can be expected that the dimensions would work in concert and reinforce one-another, creating the rare and inimitable familybased resource that Habbershon and Williams (1999) originally described. When familiness was proposed by Habbershon and Williams (1999) they aimed to increase our understanding of the origins of the competitiveness of family firms. While other researchers have focused on the consequences of familiness, and specifically, the "how" (Arregle et al., 2007) and "what" (Pearson et al., 2008) of familiness, we chose to focus on the "who" of familiness-the family. That is, we attempted to describe the families that are most likely to be able to develop familiness. Thus, we believe that our multi-dimensional model helps to explain differences among family firms, as well as differences between family and non-family firms. Additionally, our multi-dimensional model provides insight into why some family firms may behave more like non-family firms, and why some non-family firms may seem family-like.

Our attempt is thus different from other work that has sought to classify family firms and grasp the essence of family involvement. For example, with their F-PEC model of family involvement, Astrachan, Klein and Smyrnios (2002) have suggested a threedimensional measure of family involvement (see also Klein et al., 2005). While there is some overlap between our arguments on organizational identity and the culture dimension of F-PEC (i.e., the extension of values, beliefs and goals from the family to the organizational level), we see F-PEC as more of an empirical scale to sort out different types of family involvement, whereby each dimension is seen as independent. Our approach differs from F-PEC in two significant ways: first, we explore how different dimension of familiness overlap, and secondly, we add family firm identity as one of the key elements that facilitate the creation of familiness.

\section{Limitations and future research}

We need to address a few limitations of our work that also offer future research opportunities. While we discussed the family aspect of familiness, we did not investigate family resource management (Naldi et al., 2007; Sirmon \& Hitt, 2003) or processes that may help leverage these resources (e.g., Eddleston et al., 2008). Accordingly, future research should investigate mechanisms that allow family firms to successfully leverage their familiness. Research should also examine how the family aspects of familiness differentiate family firms, exploring how the different configurations affect the performance of family firms over time.
To contrast distinctive familiness, we also need to mention the possibility that restrictive familiness can also develop in a family firm. However, in this paper we chose to focus on the advantages of family influence. Yet, there should be no question that the family can also have detrimental influences that can ultimately destroy the organization and that there is a dark side of strong identification and high family involvement in the firm (for examples see Gordon \& Nicholson, 2008). For instance, a lack of business objectivity and discipline can originate from the family, thus compromising control mechanisms and creating resentment both within the family and with non-family managers. Such conflicts may eventually negate the benefits of stewardship (Eddleston \& Kellermanns, 2007; Schulze, Lubatkin, Dino, \& Buchholtz, 2001). Also, as Sundaramurthy and Kreiner (2008) suggest, integrated family and business identities may promote role ambiguity among family members, which can create conflicts, reduce interaction and communication. Regarding external communication, projecting a family firm image may create (mis)perceptions that the firm is resistant to change, stagnant, inefficient (Eddleston et al., 2008; Miller, Le Breton-Miller, \& Scholnick, 2008) or not professionally managed (Chua, Chrisman, \& Bergiel, 2009). Certainly more research is needed to explore these ideas.

While we expanded on the original conceptualization of the familiness construct (Habbershon \& Williams, 1999; Habbershon et al., 2003) by exploring the family aspects of the components of involvement, essence and family firm identity, we need to acknowledge that other theoretical approaches may complement our framework. Most notably Pearson et al. (2008) and Sharma (2008) have discussed social capital as a fruitful avenue in opening the black box of familiness. In addition, transaction cost theory (e.g., Williamson, 1975) could provide useful insights into familiness.

Another area of future research is to explore if non-family firms can ever successfully mimic familiness through the use of institutionalized practices (see also Arregle et al., 2007; Leana \& Van Buren, 1999; Pearson et al., 2008). While, we already know that the concept of family can be expanded to non-family members (Karra et al., 2006), the application of family-related constructs for non-family firms remains unclear. However, before such practices are explored, the problem of "appropriability" needs to be solved (Coff, 1999). In other words, the imitation of familiness by nonfamily firms is only useful if it actually leads to performance benefits for the firm.

Our paper focused on the origins of familiness. However, we did not discuss how family members can benefit from the generated familiness. While financial resources that flow back to the family are relatively easy to assess, the non-financial aspects, which have been referred to as socio-emotional wealth (Gómez-Mejía et al., 2007), pose greater difficulties. Indeed, both economic and noneconomic benefits derived from the firm may have the potential to influence subsequent behavior and goals of family members and their involvement and influence within the firm. Accordingly, future research is encouraged to develop a comprehensive model that addresses the relationships between each of our dimensions of family influence, economic and non-economic goals/performance and the feedback mechanisms between them.

\section{References}

Albert, S., \& Whetten, D. A. (1985). Organizational identity. In Cummings, L. L., \& Staw, B. M. (Eds.), Research in organizational behavior. vol. 7 (pp.263-295). Greenwich, CT: JAI Press.

Alvarez, S. A., \& Barney, J. B. (2004). Organizing rent generation and appropriation: Toward a theory of the entrepreneurial firm. Journal of Business Venturing, 19, 621635.

Arend, R. J. (2006). Test of the resource-based view: Do the empirics have any clothes? Strategic Organization, 4(4), 409-421. 
Arregle, J.-L., Hitt, M. A., Sirmon, D. G., \& Very, P. (2007). The development of organizational social capital: Attributes of family firms. Journal of Management Studies, 44, 72-95

Ashforth, B. E., \& Mael, F. A. (1996). Organizational identity and strategy as a context for the individual. Advances in Strategic Management (vol. 13). Greenwich, CT: JAI Press. pp. 17-62.

Astrachan, J. H., Klein, S. B., \& Smyrnios, K. X. (2002). The F-Pec scale of family influence: A proposal for solving the family business definition problem. Family Business Review, 15(1), 45-58.

Barnett, T., Eddleston, K., \& Kellermanns, F. W. (2009). Business owners' role salience, career satisfiers, and performance-related outcomes in family versus non-family firms. Family Business Review, 22(1), 39-52.

Barney, J. (1991). Firm resources and sustained competitive advantage. Journal of Management, 17(1), 99-120.

Ben-Porath, Y. (1980). The F-connection: Families, friends, and firms and the organization of exchange. Population and Development Review, 6(1), 1-30.

Brickson, S. L. (2007). Organizational identity orientation: The genesis of the role of the firm and distinct forms of social value. Academy of Management Review, 32(3), 864888 .

Cabrera-Suárez, K., Saá-Pérez, P. D., \& García-Almeida, D. (2001). The succession process from a resource- and knowledge-based view of the family firm. Family Business Review, 14(1), 37-47.

Carney, M. (2005). Corporate governance and competitive advantage in family-controlled firms. Entrepreneurship Theory and Practice, 29(3), 249-266.

Chang, E. P. C., Memili, E., Chrisman, J., Kellermanns, F. W., \& Chua, J. (2009). Venture preparation and business creation: Does family help? A report of Hispanics in the U.S. Family Business Review, 22(3), 279-292.

Chrisman, J. J., Chua, J. H., \& Kellermanns, F. W. (2009). Priorities, resource stocks, and performance in family and non-family firms. Entrepreneurship Theory and Practice, 33(3), 739-760.

Chrisman, J. J., Chua, J. H., \& Litz, R. (2003). A unified systems perspective of family firm performance: An extension and integration. Journal of Business Venturing, 18(4), 467-472.

Chrisman, J. J., Chua, J. H., Pearson, A. W., \& Barnett, T. 2009b. Family involvement family influence, and family-centered non-economic goals in small firms, Center of Family Enterprise Research Working Paper Series 09.04. Mississippi State, MS: Mississippi State University.

Chrisman, J. J., Chua, J. H., \& Sharma, P. (2005). Trends and directions in the development of a strategic management theory of the family firm. Entrepreneurship Theory and Practice, 29(5), 555-576.

Chrisman, J. J., Chua, J. H., \& Zahra, S. A. (2003). Creating wealth in family firms through managing resources: Comments and extensions. Entrepreneurship Theory and Practice, 27(4), 359-365

Chrisman, J. J., Steier, L. P., \& Chua, J. H. (2008). Toward a theoretical basis for understanding the dynamics of strategic performance in family firms. Entrepreneurship Theory and Practice, 32(6), 935-947.

Chua, J. H., Chrisman, J. J., \& Bergiel, E. B. (2009). An agency theoretic analysis of the professionalizated family firm. Entrepreneurship Theory and Practice, 33(2), 355-372.

Chua, J. H., Chrisman, J. J., \& Sharma, P. (1999). Defining the family business by behavior. Entrepreneurship Theory and Practice, 23(4), 19-39.

Coff, R. W. (1999). When competitive advantage doesn't lead to performance: The resource based view and stakeholder bargaining power. Organization Science, 10(2), 119-133.

Corbetta, G., \& Salvato, C. (2004). Self-serving or self-actualizing? Models of man and agency costs in different types of family firms: A commentary on "Comparing the agency costs of family and non-family firms: Conceptual issues and exploratory evidence". Entrepreneurship Theory and Practice, 28(4), 355-362.

Craig, J., Dibbrell, C., \& Davis, P. S. (2008). Leveraging family-based brand identity to enhance firm competitiveness and performance in family businesses. Journal of Small Business Management, 46(3), 351-371.

Danes, S. M., Stafford, K., Haynes, G., \& Amarapurkar, S. S. (2009). Family capital of family firms: Bridging human, social, and financial capital. Family Business Review $22,199-216$

Debicki, B. J., Matherne, C. F., Kellermanns, F. W., \& Chrisman, J. J. (2009). Family business research in the new millennium: An overview of the who, the where, the what, and the why. Family Business Review, 22(2), 151-166.

Dierickx, I., \& Cool, K. (1989). Asset stock accumulation and sustainability of competitive advantage. Management Science, 35(12), 1504-1514.

Dyer, G., \& Whetten, D. A. (2006). Family firms and social responsibility: Preliminary evidence from the S\&P 500. Entrepreneurship Theory and Practice, 30(6), 785-802.

Dyer, W. G. (2006). Examining the "family effect" on firm performance. Family Business Review, 19(4), 253-273.

Eddleston, K., \& Kellermanns, F. W. (2007). Destructive and productive family relationships: A stewardship theory perspective. Journal of Business Venturing, 22(4), 545565 .

Eddleston, K., Kellermanns, F. W., \& Sarathy, R. (2008). Resource configuration in family firms: Linking resources, strategic planning and environmental dynamism to performance. Journal of Management Studies, 45(1), 26-50.

Eddleston, K. A. (2009). The family as an internal and external resource to the firm: The importance of building a family firm identity, Paper presented at the Second Annual Conference of Family Capital, Family Business, and Free Enterprise. University of St Thomas, Minneapolis.

Fiol, C. M. (1991). Managing culture as a competitive resource: An identity-based view of sustainable competitive advantage. Journal of Management, 17, 191-211.

Fock, S.-T. (1998). The impact of family conflicts on the development of the Chinese entrepreneurially managed family business: The Yeo Hiap Seng Case in Singapore. Journal of Small Business \&' Entrepreneurship, 15(2), 88-103.
Fombrun, C. J., \& Shanley, M. (1990). What's in a name? Reputation building and corporate strategy. Academy of Management Journal, 33(1), 233-258.

Gallo, M., \& Vilaseca, A. (1996). Finance in family businesses. Family Business Review, $9(4), 387-402$

Gioia, D. (1998). From individual to organizational identity. In D. Whetten \& P. Godfrey (Eds.), Identity in organizations: Building theory through conversations (pp. 17-31). Thousand Oaks, CA: Sage.

Gioia, D. A., Schultz, M., \& Corley, K. G. (2000). Organizational identity, image, and adaptive instability. Academy of Management Review, 25(1), 63-81.

Goffe, R., \& Scasse, R. (1985). Proprietorial control in family firms-Some functions of quasi-organic management systems. Journal of Management Studies, 22, 53-68.

Gómez-Mejía, L. R., Hynes, K. T., Núñez-Nickel, M., \& Moyano-Fuentes, H. (2007). Socioemotional wealth and business risk in family-controlled firms: Evidence from Spanish olive oil mills. Administrative Science Quarterly, 52, 106-137.

Gordon, G., \& Nicholson, N. (2008). Family wars. Classic conflicts in family business and how to deal with them. London/Philadelphia: Kogan Page.

Grant, R. M. (1991). The resource-based theory of competitive advantage: Implications for strategy formulation. California Management Review, 33(3), 114-135.

Habbershon, T. G., \& Williams, M. (1999). A resource-based framework for assessing the strategic advantage of family firms. Family Business Review, 12, 1-25.

Habbershon, T. G., Williams, M., \& MacMillan, I. C. (2003). A unified systems perspective of family firm performance. Journal of Business Venturing, 18, 451-465.

Karra, N., Tracey, P., \& Phillips, N. (2006). Altruism and agency in the family firm: Exploring the role of family, kinship, and ethnicity. Entrepreneurship Theory and Practice, 30, 861-877.

Karreman, D., \& Rylander, A. (2008). Managing meaning through branding-The case of a consulting firm. Organization Studies, 29(1), 103-125.

Kellermanns, F. W., \& Eddleston, K. (2007). Family perspective on when conflict benefits family firm performance. Journal of Business Research: Special Issue on Family Firms, 60, 1048-1057.

Kellermanns, F. W., Eddleston, K., \& Zellweger, T. 2008. Family harmony: A facilitator of corporate entrepreneurship in family firms, Paper presented at FERC. Milwaukee, Wisconsin.

Kellermanns, F. W., Eddleston, K. A., Sarathy, R., \& Murphy, F. (in press). Innovativeness in family firms: A family influence perspective. Small Business Economics Journal.

Klein, S. B., Astrachan, J. H., \& Smyrnios, K. X. (2005). The F-PEC scale of family influence: Construct validation, and further implication for theory. Entrepreneurship Theory and Practice, 29(3), 321-339.

Leana, C. R., \& Van Buren, H. J., III (1999). Organizational social capital and employment practices. Academy of Management Review, 24(2), 538-555.

Lester, R. H., \& Cannella, A. A. (2006). Interorganizational familiness: How family firms use interlocking directorates to build community-level social capital. Entrepreneurship Theory and Practice, 30(6), 755-775.

Memili, E, Eddleston, K, Zellweger, T. Kellermanns, F. W \& Barnett T. (in press). Firm emergence and growth. New York: Emerald. The importance of looking toward the future and building on the past: Entrepreneurial risk taking and image in family firms. In Lumpkin, T. \& Steward A. (Eds.), Advances in Entrepreneurship, Firm Emergence and Growth.

Miller, D., Le Breton-Miller, I., \& Scholnick, B. (2008). Stewardship vs. stagnation: An empirical comparison of small family and non-family businesses. Journal of Management Studies, 45(1), 51-78.

Mustakallio, M., Autio, E., \& Zahra, S. A. (2002). Relational and contractual governance in family firms: Effects on strategic decision-making. Family Business Review, 15(3), 205-222.

Nag, R., Corley, K. G., \& Gioia, D. A. (2007). The intersection of organizational identity, knowledge, and practice: Attempting strategic change via knowledge grafting Academy of Management Journal, 50(4), 821-847.

Naldi, L., Nordqvist, M., Sjoberg, K., \& Wiklund, J. (2007). Entrepreneurial orientation, risk taking, and performance in family firms. Family Business Review, 20(1), 33-47.

Newbert, S. L. (2007). Empirical research on the resource-based view of the firm: An assessment and suggestions for future research. Strategic Management Journal, 28 121-146.

Nordqvist, M., \& Zellweger, T. (2010). Transgenerational entrepreneurship. Cheltenham (UK): Edward Elgar.

Pearson, A. W., Carr, J. C., \& Shaw, J. C. (2008). Toward a theory of familiness: A social capital perspective. Entrepreneurship Theory and Practice, 32(6), 949-969.

Peteraf, M. A. (1993). The cornerstone of competitive advantage: A resource-based view. Strategic Management Journal, 14, 179-191.

Priem, R. L., \& Butler, J. E. (2001). Is the resource-based "view" a useful perspective for strategic management research? Academy of Management Review, 26(1), 22 40.

Ravasi, D., \& Schultz, M. (2006). Responding to organizational identity threats: Exploring the role of organizational culture. Academy of Management Journal, 49(3), 433458

Rousseau, D. M., \& Wade-Benzoni, K. A. (1994). Linking strategy and human resource practices: How employee and customer contracts are created. Human Resource Management Review, 33, 463-489.

Rutherford, M. W., Kuratko, D. F., \& Holt, D. T. (2008). Examining the link between "Familiness" and performance: Can the F-Pec untangle the family business theory jungle? Entrepreneurship Theory and Practice, 32(6), 1089-1110.

Schulze, W. S., Lubatkin, M. H., \& Dino, R. N. (2003). Toward a theory of agency and altruism in family firms. Journal of Business Venturing, 18(4), 473-490.

Schulze, W. S., Lubatkin, M. H., Dino, R. N., \& Buchholtz, A. K. (2001). Agency relationships in family firms: Theory and evidence. Organization Science, 12(2), 99-116.

Scott, S. G., \& Lane, V. R. (2000). A stakeholder approach to organizational identity. Academy of Management Review, 25(1), 43-62. 
Sharma, P. (2008). Commentary: Familiness: Capital stocks and flows between family and business. Entrepreneurship Theory and Practice, 32(6), 971-977.

Sharma, P., Hoy, F., Astrachan, J. H., \& Koiranen, M. (2007). The practice-driven evolution of family business education. Journal of Business Research, 60(10), 1012-1021.

Sirmon, D. G., Arregle, J.-L., Hitt, M. A., \& Webb, J. W. (2008). The role of family influence in firms' strategic responses to threat of imitation. Entrepreneurship Theory and Practice, 32(6), 979-998.

Sirmon, D. G., \& Hitt, M. A. (2003). Managing resources: Linking unique resources, management and wealth creation in family firms. Entrepreneurship Theory and Practice, 27(4), 339-358.

Smidts, A. Pruyn, A. H., \& Van Riel, C. B. M. (2001). The impact of employee communication and perceived external prestige on organizational identification. Academy of Management Journal, 49(5), 1051-1062.

Sorenson, R. L., Goodpaster, K. E., Hedberg, P. R., \& Yu, A. (2009). The family point of view, family social capital, and firm performance: An exploratory test. Family Business Review, 22(3), 239-253.

Steier, L. (2003). Variants of agency contracts in family financed ventures as a continuum of familial altruisitic and market rationalities. Journal of Business Venturing, 18, 597-618.

Sundaramurthy, C., \& Kreiner, G. E. (2008). Governing by managing identity boundaries: The case of family businesses. Entrepreneurship Theory and Practice, 32(3), 415-436.

Tagiuri, R., \& Davis, J. A. (1992). On the goals of successful family companies. Family Business Review, 5(1), 43-62.

Ueda, M. (2004). Banks versus venture capital: Project evaluation, screening, and expropriation. Journal of Finance, 59, 6001-6621.

Van Auken, H., \& Werbel, J. (2006). Family dynamic and family business financial performance: Spousal commitment. Family Business Review, 19(1), 49-63.
Ward, J., \& Aronoff, C. E. (1995). Family-owned businesses: A thing of the past or a model for the future. Family Business Review, 8(2), 121-130.

Weick, K. E. (1995). Sensemaking in organizations. Thousand Oaks, CA: Sage.

Westhead, P., \& Cowling, M. (1998). Family firm research: The need for a methodological rethink. Entrepreneurship Theory and Practice, 23(1), 31-56.

Westhead, P., \& Howorth, C. (2007). 'Types' of private family firm: An exploratory conceptual and empirical analysis. Entrepreneurship \& Regional Development, 19, 405-431.

Whetten, D., \& Mackey, A. (2002). A social actor conception of organizational identity and its implications for the study of organizational reputation. Business and Society, 41(4), 393-415.

Williamson, O. E. (1975). The economics of organization: The transaction cost approach. American Journal of Sociology, 87, 548-577.

Zahra, S. A., Hayton, J. C., Neubaum, D. O., Dibrell, C., \& Craig, J. (2008). Culture of family commitment and strategic flexibility: The moderating effect of stewardship. Entrepreneurship Theory and Practice, 32(6), 1035-1054.

Zahra, S. A., \& Sharma, P. (2004). Family business research: A strategic reflection. Family Business Review, 17(4), 331-346.

Zellweger, T. (2007). Time horizon, costs of equity capital and generic investment strategies of firms. Family Business Review, 20(1), 1-15.

Zellweger, T., \& Astrachan, J. (2008). On the emotional value of owning a firm. Family Business Review, 21(4), 347-363.

Zellweger, T., \& Kellermanns, F. W. (2008). Family firm reputation: An investigation of antecedents and performance outcomes. Anaheim, CA: Academy of Management Presentation.

Zellweger, T. M., \& Nason, R. S. (2008). A stakeholder perspective on family firm performance. Family Business Review, 21(3), 203-216. 